\title{
SENZORICKÉ VLASTNOSTI METAKAOLINOVÉHO GEOPOLYMERU S UHLÍKOVÝMI NANOTRUBIČKAMI PŘI ZATĚŽOVÁNÍ V TLAKU
}

\author{
SELF-SENSING PROPERTIES OF METAKAOLIN GEOPOLYMER WITH \\ CARBON NANOTUBES UNDER COMPRESSIVE LOADING
}

\author{
Cecílie Mizerová*, ${ }^{*}$, Pavel Rovnaník ${ }^{1}$, Ivo Kusák ${ }^{1}$, Pavel Schmid ${ }^{1}$
}

"mizerova.c@fee.vutbr.cz

${ }^{1}$ Vysoké učení technické v Brně, Fakulta stavební, Veveří 331/95, 60200 Brno

\begin{abstract}
Abstrakt
Zvýšená schopnost alkalicky aktivovaných pojiv přenášet elektrický náboj se stala atraktivním tématem ve výzkumu věnovaném multifunkčním materiálům se senzorickými, samozahřívacími a dalšími progresivními vlastnostmi. Tato studie je zaměřena na senzorické vlastnosti metakaolinových geopolymerních malt s 0,05 a $0,10 \%$ uhlíkových nanotrubiček při cyklickém zatěžování v tlaku. Zkušební tělesa s vloženými měděnými elektrodami byla podrobena dvěma různým režimům tlakového zatěžování s kontinuálním sledováním napětí a elektrického odporu. Referenční i modifikované geopolymerní malty vykazovaly dobrou odezvu na působící zatížení, presto byly zaznamenány změny v citlivosti a strukturních deformacích.
\end{abstract}

\section{Klíčová slova}

Geopolymer, metakaolin, uhlíkové nanotrubičky, senzorické vlastnosti, tlakové namáhání

\begin{abstract}
Increased capability of alkaline activated binders to transfer the electric charge became an attractive issue in research related to multifunctional materials with self-sensing, self-heating and other progressive properties. This study is focused on self-sensing properties of metakaolin geopolymer mortars with 0.05 and $0.10 \%$ carbon nanotubes under repeated compressive loading. Specimens incorporated with copper electrodes were subjected to two different regimes of compressive loading with continuous monitoring of strain and electrical resistance. Both reference and modified geopolymer mortars have shown good response to applied loading, yet the differences in sensitivity and structural deformations were observed.
\end{abstract}

Key words

Geopolymer, metakaolin, carbon nanotubes, self-sensing properties, compressive loading

\section{1 ÚVOD}

Geopolymery jsou poměrně novou skupinou anorganických pojiv, která se vyrábějí alkalickou aktivací př́rodních, zpracovaných nebo odpadních surovin tvořených téměř výhradně hlinitokřemičitanovou složkou, např. popílku nebo metakaolinu. Název geopolymer je odvozen od velmi pravidelné struktury pojiva tvořené strukturními jednotkami $\mathrm{SiO}_{4}{ }^{4-}$ a $\mathrm{AlO}_{4}{ }^{5-}$, která vzniká po smíchání s alkalickým aktivátorem [1]. Výhodou geopolymerů je kromě dobrých mechanických vlastností také vysoká chemická odolnost, tepelná stabilita a často menší ekologická zátěž ve srovnání s cementovými pojivy [2]. V posledních letech se navíc ukazuje, že v některých vlastnostech se alkalicky aktivované materiály značně odlišují od cementových pojiv a mohou být využity pro nové netradiční aplikace, zejména pro multifunkční kompozity [3].

Jednou ze skupin takových materiálů jsou materiály se zvýšenou elektrickou vodivostí, které by mohly být využívány např. pro návrh samozahřívacích betonů, materiálů se senzorickými vlastnostmi nebo pro stínění elektromagnetického záření [4]. Vzhledem $\mathrm{k}$ tomu, že klasický beton je považován za elektrický izolant, je často nutné do těchto kompozitů přidat vhodné vodivé plnivo. Nejčastěji se jedná o plnivo na bázi uhlíku nebo kovu, např. ocelová vlákna, uhlíkové saze, uhlíková vlákna (CF), uhlíkové nanotrubičky (CNTs) nebo grafit [5]. Podmínkou použitelnosti funkčního plniva je dobrá elektrická vodivost, odolnost v zásaditém prostředí, 
kompatibilita s vybraným pojivem a minimální negativní vliv na vlastnosti pojiva v čerstvém stavu i po zatvrdnutí [4]. První práce věnující se betonům se senzorickými vlastnostmi, které sledovaly závislost působícího zatížení a změny elektrického odporu materiálu, se datují do 90. let. Při měření senzorických vlastností se zaznamenává elektrický odpor př́ípadně jiná veličina, která reaguje na změny mechanického zatížení, napětí, tvorbu trhlin či jiných poruch, ale také okolních podmínek (teplota, vlhkost) [5].

Z porovnání elektrických vlastností cementové a alkalicky aktivované matrice vyplývá, že především metakaolinový geopolymer a alkalicky aktivovaná struska vykazují zvýšenou elektrickou vodivost, která se připisuje př́tomnosti velkého množství pohyblivých hydratovaných alkalických iontů a vhodné pórové struktuře pojiva [7], případně také obsahu iontů Fe a jiných kovů [8]. Piezoresistivní odezva byla pozorována u geopolymerů [9] i alkalicky aktivované strusky při tlakovém namáhání [8], a to i bez přítomnosti vodivého plniva. Vlachakis [10] nicméně uvádí, že i u geopolymerů je vhodné funkční plnivo použít, nebot' rozdíly ve vodivosti různých typů matrice a funkčního plniva mohou být výrazné. Aplikací vodivého plniva se dále eliminuje pokles vodivosti v důsledku vysychání matrice.

Uhlíkové nanotrubičky (CNTs) jsou tubulární útvary, jejichž jednu případně více stěn tvoří sít’ šestiúhelníků atomů uhlíku. Kromě výborné tepelné a elektrické vodivosti mají CNTs díky vysokému poměru mezi délkou a průměrem také výjimečné mechanické vlastnosti, zejména v tahu [5], [11]. Pro aplikaci ve vodivých kompozitech se dávkují v nízkých koncentracích, kde je nejpodstatnější jejich homogenní dispergace [11], ke které částečně přispívá také zásadité prostředí alkalického aktivátoru [12]. U geopolymerů s obsahem CNTs došlo ke zvýšení elektrické vodivosti a také citlivosti odezvy při měření senzorických vlastností vyjádřené tzv. gauge faktorem $(G F)$, přičemž $G F$ byl mnohem vyšší ve srovnání s cementovou matricí s jakýmkoli typem vodivého plniva. $G F$ se stanoví ze změny elektrického odporu a přetvoření dle vztahu (1):

$$
G F=\frac{\Delta R / R_{0}}{\Delta L / L_{0}}=\frac{\Delta R / R_{0}}{\varepsilon}=1+2 v+\frac{\Delta \rho / \rho_{0}}{\varepsilon},
$$

kde $G F$ je gauge faktor [-], $\Delta R$ absolutní změna elektrického odporu [ $\Omega], R_{0}$ počáteční elektrický odpor [ $\left.\Omega\right], \Delta L$ absolutní délková změna $[\mathrm{m}], L_{0}$ počáteční délka $[\mathrm{m}], \varepsilon$ poměrná deformace (přetvoření) $[-], \Delta \rho$ absolutní změna rezistivity $[\Omega \cdot \mathrm{m}], \rho$ počáteční rezistivita $[\Omega \cdot \mathrm{m}]$ a $v$ Poissonovo číslo $[-]$.

Tento příspěvek je zaměřen na měření a interpretaci senzorických vlastností metakaolinového geopolymeru s obsahem CNTs, který byl vystaven cyklickému tlakovému namáhání. Senzorické chování kompozitů je diskutováno $\mathrm{v}$ souvislosti $\mathrm{s}$ přetvořením zkušebních těles a odpovídající relativní změnou elektrického odporu. Relativní změna elektrického odporu $\left(\left(R-R_{0}\right) / R_{0}\right)$ byla použita $\mathrm{k}$ hodnocení citlivosti a reprodukovatelnosti měřeného výstupního signálu nebo deformací.

\section{METODIKA}

\section{Materiály a výroba zkušebních těles}

Hlavními surovinami pro výrobu geopolymerních malt byl metakaolin Mefisto K05 (České lupkové závody, a. s.) obsahující 55,01\% $\mathrm{SiO}_{2}$ a 40,94\% $\mathrm{Al}_{2} \mathrm{O}_{3}$ a dále alkalický aktivátor sestávající z vodního skla a 30\% roztoku $\mathrm{NaOH}$, jako plnivo byl použit standardní křemičitý písek s maximální velikostí zrna 2,5 mm. Vodivé plnivo, uhlíkové nanotrubičky (CNTs) Graphistrength ${ }^{\circledR}$ C100 (Arkema), bylo dávkováno ve formě 2\% roztoku připraveného rozpuštěním a dispergací pevných aglomerátů CNTs v horké vodě. Koncentrace CNTs v modifikovaných maltách byla 0,05 a $0,10 \%$.

Při přípravě malt dle receptur uvedených v Tab. 1 bylo nejprve smícháno vodní sklo, roztok hydroxidu, voda a roztok CNTs. Do homogenní suspenze byl postupně přidán metakaolin a zamíchán do hladké pasty. Nakonec byly přidány všechny frakce kameniva. Čerstvou směsí byly naplněny krychlové formy $(100 \times 100 \times 100 \mathrm{~mm})$, do kterých byly pomocí destičky z voděodolné překližky s drážkami rozmístěny 4 elektrody z měděné mř́žky o rozměrech $80 \times 120 \mathrm{~mm}$ (ve vzdálenosti $20 \mathrm{~mm}$ od sebe). Vzorky byly poté zakryty folií a uloženy v laboratoří.

Tab. 1 Receptury geopolymerních malt.

\begin{tabular}{cccc}
\hline & REF & CNT0,05 & CNT0,10 \\
\hline Metakaolin (g) & 900 & 900 & 900 \\
Vodní sklo (g) & 748 & 748 & 748 \\
$\mathbf{3 0 \% ~ N a O H ~ ( g ) ~}$ & 83 & 83 & 83 \\
Písek (g) & 2700 & 2700 & 2700 \\
$\mathbf{2 \%}$ roztok CNT (g) & - & 22,5 & 45 \\
Voda (g) & 103 & 80,5 & 58 \\
\hline
\end{tabular}




\section{Experimentální část}

Měření senzorických vlastností v tlaku probíhalo v elektromechanickém zkušebním lisu LabTest ${ }^{\circledR} 6.250$ (Labortech) umožňujícím maximální zatížení 250 kN. Cyklické tlakové zatěžování zkušebních těles probíhalo ve směru kolmém na rovinu vložených elektrod (viz Obr. 1) ve dvou zkušebních režimech: a. 10 cyklů s konstantní amplitudou $10 \mathrm{kN}$ (rychlost zatěžování $300 \mathrm{kN} / \mathrm{s}$ ), b. 30 cyklů s proměnnou amplitudou 7-35 kN (rychlost zatěžování $500 \mathrm{kN} / \mathrm{s}$ ). Maximální zatížení vzorků přitom nepřesáhlo $25 \%$ jejich pevnosti v tlaku.

Měření senzorických vlastností kompozitů probíhalo za stř́́davého elektrického proudu o frekvenci $1 \mathrm{kHz}$ s využitím generátoru sinusového signálu Agilent 33220A a dvou multimetrů Agilent 34410A. Generovaný signál byl přenášen na vnější elektrody a vnitřní elektrody sloužily k měření výstupního elektrického napětí (vstupní hodnota elektrického napětí byla $5 \mathrm{~V}$ ). Elektrický odpor byl určen výpočtem z naměřeného elektrického napětí a procházejícího elektrického proudu podle Ohmova zákona.

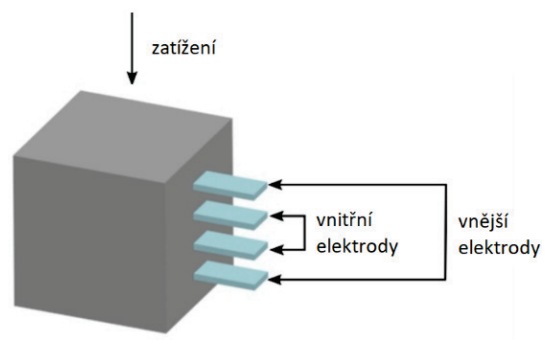

Obr. 1 Uspořádání elektrod vzhledem ke směru působícího zatížení (upraveno dle [10]).

\section{VÝSLEDKY A DISKUZE}

\section{Lineární tlakové namáhání s konstantní amplitudou (10 cyklů)}

V první fázi měření senzorických vlastností v tlaku byla zkušební tělesa podrobena 10 zatěžovacím cyklům, režim zatěžování a přetvoření těles měřené pomocí osazeného tenzometru je zobrazeno na Obr. 2 (a). Z grafu je patrné, že deformace vzorků REF a CNT0,05 byla srovnatelná a dosahující hodnoty přibližně $60 \mu \mathrm{m} / \mathrm{m}$, zatímco u vzorku CNT0,10 byla maximální deformace více než dvojnásobná. Maximální přetvoření referenčního materiálu se s přibývajícími cykly mírně snižovalo.

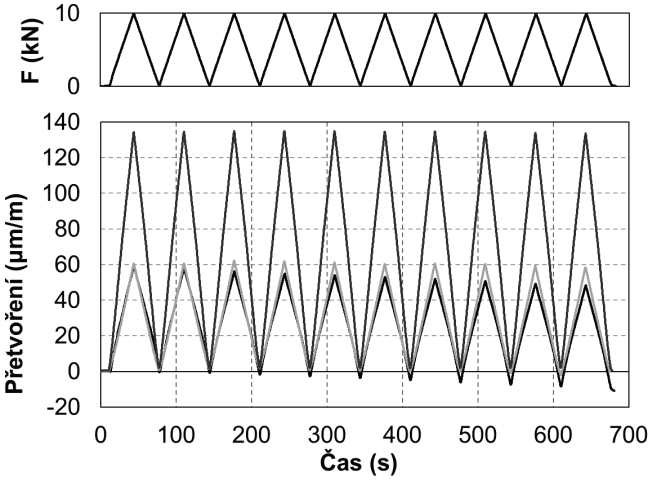

(a)

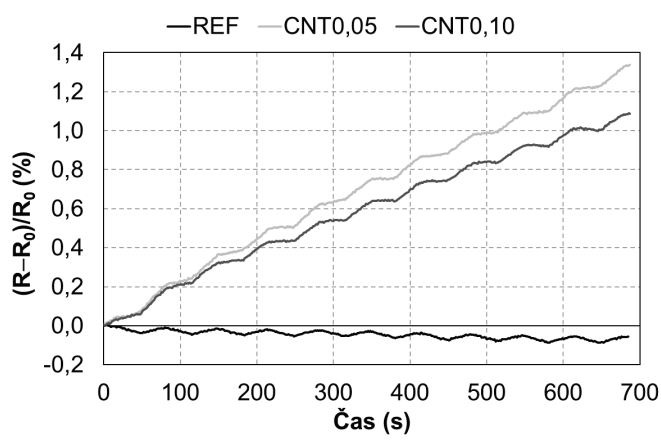

(b)

Obr. 2 (a) přetvoření zkušebních těles, (b) relativní změna elektrického odporu během lineárního tlakového namáhání s konstantní amplitudou.

Piezorezistivní odezva byla patrná u všech zkušebních těles, jak ukazuje graf na Obr. 2 (b), kde relativní změna elektrického odporu dobře reaguje na příslušné zatěžovací cykly. Graf však ukazuje, že u zkušebních těles s CNTs 
došlo k postupnému nárůstu elektrického odporu, což dokládá vznik permanentních deformací, které se projevují přerušením vodivé sítě. U referenčního materiálu byl zaznamenán opačný trend, tj. klesající celkový elektrický odpor. K podobným závěrům dospěla i studie věnovaná alkalicky aktivované strusce s 0,5 až $2 \% \mathrm{CF}$, kde nedošlo ke zlepšení senzorických vlastností v důsledku tvorby mikrotrhlin [13]. Naopak použití 10 \% grafitu [14] či 0,5\% uhlíkových sazí [15] v popílkové geopolymerní maltě zlepšilo jak citlivost, tak opakovatelnost odezvy při měření senzorických vlastností. Uhlíkové saze v nízké koncentraci měly navíc minimální negativní dopad na mechanické vlastnosti kompozitu.

\section{Lineární tlakové namáhání s proměnnou amplitudou (30 cyklů)}

Ve druhé fázi byla zkušební tělesa zatěžována 30 cykly s rostoucí a klesající amplitudou v rozmezí 7-35 kN (Obr. 3 (a)), přičemž chování jednotlivých vzorků v závislosti na zatížení bylo podobné jako v předchozím případě. Vzorek CNT0,10 opět dosáhl největších deformací, přetvoření vzorků REF a CNT0,05 se příliš nelišilo. U maximálních deformací byly zaznamenány menší změny s přibývajícími zatěžovacími cykly.

Vývoj relativní změny elektrického odporu v grafu na Obr. 3 (b) opět ukazuje na vznik plastických deformací u vzorků s obsahem CNTs. Stejně jako u zatěžování s konstantní amplitudou dosáhl největších trvalých deformací vzorek CNT0,05. Vyšší hodnoty plastických deformací u kompozitů s obsahem CNTs pozorované v této studii nejsou v souladu s již publikovanými výsledky, které většinou uvádějí zlepšení modulu pružnosti a jiných mechanických vlastností modifikovaných geopolymerů.

Odezva referenčního materiálu naopak dobře korespondovala s působícím zatížením, u celkového elektrického odporu došlo pouze k nepatrným změnám a citlivost se pohybovala kolem $0,10-0,15$ \% při maximálním zatížení. Potenciální př́nos CNTs ke zlepšení senzorických vlastností tedy nebyl naplněn z důvodu setrvalého nárůstu elektrického odporu $\mathrm{v}$ důsledku trvalých deformací. U referenčního materiálu byla sledována velmi dobrá opakovatelnost a reprodukovatelnost závislosti relativní změny elektrického odporu na zatěžovací cykly, nejméně příznivých výsledků dosáhl vzorek CNT0,05. Vývoj relativní změny elektrického odporu u vzorku CNT0,10 naznačuje, že zejména citlivost u maximální hodnoty zatížení by mohla být i vyšší ve srovnání s REF, nicméně tento efekt byl převážen nárůstem celkového elektrického odporu.

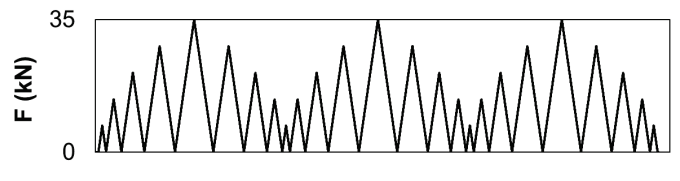

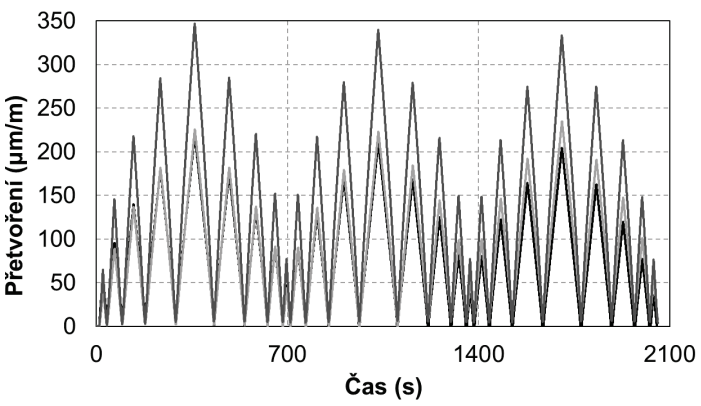

(a)

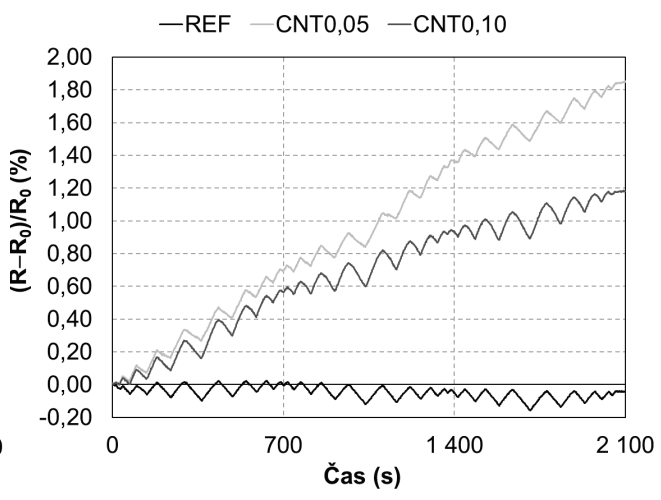

(b)

Obr. 3 (a) přetvoření zkušebních těles, (b) relativní změna elektrického odporu během lineárního tlakového namáhání s proměnnou amplitudou.

\section{ZÁVĚR}

Cílem studie bylo zhodnocení vlivu uhlíkových nanotrubiček (CNTs) jako vodivého pojiva na senzorické vlastnosti metakaolinového geopolymeru při cyklickém namáhání v tlaku. Vzorky z referenčního materiálu a pojiva s obsahem 0,05 a $0,10 \%$ CNTs byly podrobeny cyklickému zatěžování v tlaku ve dvou zkušebních režimech, nejprve s konstantní a poté s proměnnou amplitudou. Ze sledování relativních změn elektrického odporu je patrné, že všechny vzorky vykazují dobrou odezvu na působící zatížení, senzorické vlastnosti vzorků s obsahem CNTs však byly negativně ovlivněny postupně narůstající mírou trvalých deformací. Tento závěr není zcela v souladu s dř́ve publikovanými výsledky jiných autorů, které častěji poukazovaly na zlepšení mechanických 
vlastností materiálů modifikovaných CNTs. Příčina tohoto jevu není zcela jasná, ale může být ovlivněna např. nedokonalou dispergací CNTs. Mechanické a elektrické vlastnosti kompozitů budou ve vztahu k jejich senzorickým schopnostem dále zkoumány např. při ohybovém namáhání nebo př̀i namáhání do porušení.

\section{Poděkování}

Financování tohoto výstupu bylo podpořeno Grantovou agenturou České republiky v rámci projektu 19-11516S a prostředky juniorského specifického výzkumu VUT FAST-J-21-7478.

\section{Použité zdroje}

[1] Provis J L and Bernal S A 2014 Geopolymers and related alkali-activated materials Annual Review of Mat. Res. 44 299-327

[2] Matheu P S, Ellis K and Varela B 2015 Comparing the environmental impacts of alkali activated mortar and traditional portland cement mortar using life cycle assessment. IOP Conference Series: Mat. Sci. and Eng. 96012080

[3] Tang Z, Li W, Hu Y, Zhou J L and Tam V W 2019 Review on designs and properties of multifunctional alkali-activated materials (AAMs) Constr. Build. Mat. 200 474-489

[4] Han B, Yu X. and Ou J 2014 Self-sensing concrete in smart structures (Butterworth-Heinemann)

[5] Chung D D L 2012 Carbon materials for structural self-sensing, electromagnetic shielding and thermal interfacing Carbon 50(9) 3342-3353

[6] Han B, Zhang L and Ou J 2017 Smart and multifunctional concrete toward sustainable infrastructures (Singapore: Springer) 369-377

[7] Hanjitsuwan S, Chindaprasirt P and Pimraksa K 2011 Electrical conductivity and dielectric property of fly ash geopolymer pastes Int. Jour. of Miner. Metall. Mat. 18(1) 94-99

[8] Rovnaník P, Kusák I, Bayer P, Schmid P and Fiala L 2019 Comparison of electrical and self-sensing properties of Portland cement and alkali-activated slag mortars Cem. Concr. Res. 118 84-91

[9] Lamuta C, Candamano S, Crea F and Pagnotta L 2016 Direct piezoelectric effect in geopolymeric mortars Mat. \& Design 107 57-64

[10] Vlachakis C, Perry M and Biondi L 2020 Self-sensing alkali-activated materials: a review. Minerals 10(10) 885

[11] Dai H 2002 Carbon nanotubes: synthesis, integration, and properties Accounts of Chem. Res. 35(12) 1035-1044

[12] Su Z, Hou W and Sun Z 2020 Recent advances in carbon nanotube-geopolymer composite Constr. Build. Mat. 252118940

[13] Rovnaník P, Kusák I, Topolář L and Schmid P 2019 Sensing properties of slag-based geopolymer composite with carbon fibers under compressive loading

[14] Rovnaník P, Kusák I and Schmid P 2021 Self-sensing properties of fly ash geopolymer composite with graphite filler AIP Conf. Proceed. 2322(1) 020016 AIP Publishing LLC

[15] Mizerová C, Kusák I, Topolár L, Schmid P and Rovnaník P 2021 Self-Sensing Properties of Fly Ash Geopolymer Doped with Carbon Black under Compression. Mat. 14(16) 4350 